\title{
PROPRIETATEA FUND: A SUCCINCT OVERVIEW
}

Cornelia Pop, Department of Business, Faculty of Business, Babes-Bolyai University, Romania Marius Gavriletea, Department of Business, Faculty of Business, Babes-Bolyai University, Romania

dx.doi.org/10.18374//JBR-13-4.19

\begin{abstract}
Bucharest Stock Exchange is considered a frontier market and it is dominated by the financial sector trading. Starting with January 25th 2011, Proprietatea Fund, a closed-end investment Fund, starts listing at BVB increasing the dominance of the financial sector. The present paper briefly investigates the causes that generated the intense trading activity of this investment Fund shares between January 2011 and June 2013.
\end{abstract}

Keywords: Bucharest Stock Exchange, Proprietatea Fund, Investments 